DOI https://doi.org/10.30525/978-9934-588-91-4-10

\title{
THE MEMORIALISATION OF PILSUDSKI - PETLIURA TREATY OF 1920
}

\author{
Brahina T. \\ Candidate of Philosophical Sciences, \\ Associate Professor at the Department of Culturology \\ Kharkiv State Academy of Culture \\ Kharkiv, Ukraine \\ Bilyk O. \\ Doctor of Pedagogical Sciences, \\ Associate Professor at the Department of Culturology \\ Kharkiv State Academy of Culture \\ Kharkiv, Ukraine \\ Brahin Y. \\ Candidate of Cultural Studies, \\ Senior lecture at the Department of Culture \\ Petro Vasylenko National Technical Univercity of Agriculture
}

Kharkiv, Ukraine

This year we celebrate the centenary of the Ukrainian-Polish Union inaugurated by the Warsaw Pact. This historical event is engraved in historicalcultural memory of Ukraine and Poland, which pay its due to the outstanding personalities of Simon Petliura and Józef Pilsudski.

The Zeitgeist of 1920 fills the memory of our contemporaries with meaning of Ukrainian-Polish fraternity. The Flame of Brotherhood campaign, held in Poland by scouts of the Polish Scouting Union and members of the Ukrainian Scout organization Plast, is especially important. These young zealots believe in common Polish-Ukrainian future. The indorsement of the memories of Ukrainian-Polish union is the activity of Polish and Ukrainian journalists, who in the 2020 May anniversary of the liberation of Kyiv by Pilsudski and Petliura honored the burial places of Polish legionnaires and soldiers of the UPR army. In the historical and cultural memories, the Warsaw Pact remains a union of two charismatic political leaders. However, their actions did not find support by national political elites.

Ukrainian diplomats found themselves in a difficult situation and were forced to compromise and make unpopular arrangements. As a result of negotiations with Prime Minister and Minister of Foreign Affairs I. Paderevsky on May 24 was signed a declaration declaring the readiness of the UPR to conclude a military-political alliance on favorable terms for Poland: the 
renouncement of UPR claims to Eastern Galicia and Volyn with the border on the river Zbruch. The Polish side accepted the obligation to assist the UPR Army in the joint fight against the Bolsheviks. But the recognition of Ukraine's independence was postponed till liberation of UPR with the help of Poland and the formation of a new government. Special paragraph stated that foreign policy of the UPR must be reconciled with Warsaw. Even Polish historians, in particular, S. Shaidak, recognized that it was an agreement of unequal partners, and Ukraine could have become a satellite of Poland [1].

The Warsaw Pact of 1920 was a milestone in the activities of Ukrainian diplomacy in the defense of independence of Ukraine. The works of the then Ukrainian and Polish politicians and the contemporary historical studies determinately attest to the important achievements of the Ukrainian-Polish military-political union. Meanwhile, this event was ambiguiously appreciated by both Ukrainian and Polish society.

The first opponents to the Warsaw Pact in Ukraine were the leaders of the s socialist parties that rallied around the government of I. Mazepa. At a meeting in Kamianets-Podilskyi, they signed a statement stating: «The socialist parties cannot sanction a military march of Polish troops in Ukrainian territory» [2, v.2, p.33].

To support the opposition I. Mazepa resigned in May. Later he wrote that the Warsaw Pact ignited the discontent in Ukrainian society with the ukrainian government in exile (and especially in Galicia province). The accusations were directed mainly against S. Petliura. M. Hrushevsky, V. Vinnychenko, M. Shapoval considered Warsaw agreement to be the betrayal of the Ukrainian interests. S. Shelukhin stated that Petliura had no right to make a decision without the Directory consent. The Galicians were outraged by the fact that Poland had in fact acquired a large part of the Ukrainian territory, where at least 10 million of Ukrainians lived.

V. Vynnychenko also opposed the agreement. The Warsaw Pact was met with hostility by many influential polish politicians. The heated discussions were held. But a benevolent attitude to Ukraine, firm will and pragmatism of Pilsudski overcome. The recognizing of Ukrainian independence and a Polish-Ukrainian military-political alliance was encouraged by Pilsudski in contradiction to the policies of the Entente. He also started fighting against the Bolsheviks in Ukraine without the consent of Paris. Countries of the Entente, especially England, were generally against the Polish-Bolshevik war. Yet Pilsudski did not take into account the opinion of The Entente countries and tried to help the UPR to gain international recognition.

It should be noted that the Warsaw Pact of 1920 and Ukrainian-Polish military-political union did not last long. They disintegrated under the influence of foreign policy factors. It was a result of the negative attitude of the Entente to the Ukraine. The ambiguous attitude of political elites to this 
union, although it was prompted by the struggle against a common enemy the Bolshevik Russia, caused a long delay in signing the agreement.

We should recognize the pragmatism of J. Pilsudski, who was guided primarily by interests of Poland. At the same time, the Warsaw Pact opened the way for the entry of Ukraine into international arena. Owing to his efforts and support of Poland Ukraine continued armed struggle for independence against the Bolsheviks in 1920. Together with Polish army Ukraine thwarted Moscow's plans of invasion of Western Europe. The transfer of the «world revolution» was aborted.

These accomplishments contributed to the strengthening of state formations in the western lands of post-imperial Russia: Finland, Estonia, Latvia, Lithuania. As a result of 1920 war the state of Poland solidified and gained international prestige [3, p. 321].

S. Petliura summoned politicians to estimate the Warsaw Pact objectively. He stressed that the fate of Ukrainian state would be doubtful without the Polish-Ukrainian agreement. Although Poles betrayed us, he pondered, we strengthened our power and clearly determined our future [4, p. 339]. Because of the non-recognition of Ukrainian independence by The Entente countries, the republican government could rely only on the support of Poland, which was bought by the cost of the Eastern Galicia inclusion to Poland. Thus only the Poland was interested in the liberation of Ukraine. S. Petliura set a goal of prompt union with Poland, and after that with the Entente countries, - «such a step was urgently required by the foreign policy and military situation» [4, p. 342].

The Warsaw Pact, also known as the Pilsudski-Petliura Treaty, according to modern researchers of Ukrainian-Polish relations, has become «an attempt to implement the «federal» conception of J. Pilsudski» [5, p. 385]. Despite the fact that the text of the agreement was secret, its general content very quickly received wide resonance in political circles of both countries.

\section{Література:}

1. Дацків I. Варшавський договір 1920 року в історії української дипломатії. Україна - Свропа - Світ. Міжнародний збірник наукових праџь. Серія: Історія міжнародних відносин. 2015. Вип. 16 (2). С. 125-132.

2. Мазепа I. Україна в огні й бурі революції, 1917 - 1921: (спогади): в 3 т.. Прага: Пробоєм, 1942. Т. 2: Кам'янецька доба. Зимовий похід. 1942. $232 \mathrm{c}$.

3. Литвин С. Суд історії: Симон Петлюра і петлюріана. Київ : Видавничий дім Олена Теліга. 2001. 645 с.

4. Павлюк О., Сідак В. Дипломатія незалежних українських урядів (1917 - 1920). Нариси з історії дипломатії України. Київ: Альтернативи. 2001. С. 314-396.

5. History of the Modern Ukrainian State, 1917-1923. Munich, 1966. $365 \mathrm{p}$. 